\title{
Non-Aromatic Hydrocarbons in Recent Sediments of Sepetiba and Ilha Grande Bays, Brazil
}

\author{
Luis H. M. Figueiredo, ${ }^{b}$ Angela de L. R. Wagener, ${ }^{* a}$ Jacques Dagaut ${ }^{c}$ and Alain Saliot ${ }^{c}$
}

${ }^{a}$ Departamento de Química, Pontifícia Universidade Católica do Rio de Janeiro, Rua Marquês de São Vicente, 225, 22453-900 Rio de Janeiro-RJ, Brazil

${ }^{b}$ Departamento de Oceanografia, Universidade do Estado do Rio de Janeiro, Rua São Francisco Xavier, 524, sala 4018 E, 20550-013 Rio de Janeiro-RJ, Brazil

${ }^{c}$ Laboratoire LOCEAN, Université Pierre et Marie Curie, IPSL/UPMC/UMR CNRS n 7159, Tour 46-00, Case Courrier 100, 4 Place Jussieu, F-75252 Paris cedex 05, France

\begin{abstract}
Realizou-se uma investigação nas Baías de Ilha Grande e de Sepetiba sobre a natureza dos hidrocarbonetos não-aromáticos (NAH) em seus sedimentos. A mistura complexa não resolvida (UCM) constituiu de 50 a 90\% da concentração dos NAH, que variou entre $2,5 \mu \mathrm{g} \mathrm{g}^{-1}$ e 193,8 $\mu \mathrm{g} \mathrm{g}^{-1}$. $\mathrm{Na}$ maior parte das amostras a distribuição dos n-alcanos foi unimodal com predomínio de compostos de número ímpar de átomos de carbono e máximos em $n \mathrm{C}_{29} \mathrm{e} n \mathrm{C}_{31}$. Monolefinas ocorreram em baixas concentrações, enquanto as poliolefinas, incluindo isoprenoides ramificados e esqualeno, variaram entre $0,099 \mu \mathrm{g} \mathrm{g}^{-1} \mathrm{e} 1,387 \mu \mathrm{g} \mathrm{g}^{-1}$, com os baixos valores relativos aos NAH surgindo em áreas de forte influência continental e antrópica. $\mathrm{C}_{27}-\mathrm{C}_{33}$ hopanos foram encontrados em todas as amostras, assim como houve predominância da configuração $17 \alpha(\mathrm{H}), 21 \beta(\mathrm{H})$, característica de origem petrogênica.
\end{abstract}

An investigation was conducted in Ilha Grande and Sepetiba Bays aiming at identifying the nature of non-aromatic hydrocarbons (NAH) in surface sediments. NAH concentrations ranged from $2.5 \mu \mathrm{g} \mathrm{g}^{-1}$ to $193.8 \mu \mathrm{g} \mathrm{g}^{-1}$ of which the major fraction (53 to 93\%) was composed by unresolved complex mixture (UMC). In most samples n-alkane distribution was dominated by compounds of odd carbon number showing maxima in $n \mathrm{C}_{29}$ and $n \mathrm{C}_{31}$. Mono-olefins were at low concentrations and the polyolefins including highly branched isoprenoids and squalene varied from $0.099 \mu \mathrm{g} \mathrm{g}^{-1}$ to $1.387 \mu \mathrm{g} \mathrm{g}^{-1}$ with lower values relative to $\mathrm{NAH}$ appearing in areas of strong terrestrial and anthropogenic influence. Hopanes between $\mathrm{C}_{27}$ and $\mathrm{C}_{33}$ were observed in all samples with the predominant configuration $17 \alpha(\mathrm{H}), 21 \beta(\mathrm{H})$, characteristic of a petrogenic origin.

Keywords: non-aromatic hydrocarbons, sediments, Ilha Grande Bay, Sepetiba Bay

\section{Introduction}

Estuarine systems are zones of transport, recycling and deposition of organic matter derived from autochthonous biological productivity, from land drainage and anthropogenic inputs. Hydrocarbons are component of organic matter derived as much from natural sources as from petroleum and by-products. Some hydrocarbons are useful molecular markers as their structural and stereochemical variations provide evidences about their origin and biological or diagenetic modifications. ${ }^{1}$

Frequently, hydrocarbons are found in marine

*e-mail: angela@rdc.puc-rio.br sediments as complex mixtures of substances derived from multiple processes, as for instance, biosynthesis, biomass burning, early diagenesis of biogenic precursors, erosion of terrestrial sediments, exudation from ocean floor and anthropogenic activities. ${ }^{2,3}$

Most plants and animals synthesize non-aromatic hydrocarbon (NAH) comprising homologous series of $n$-alkanes and $n$-alkenes, cyclic alkenes, saturated and unsaturated isoprenoid compounds and triterpenes. ${ }^{4-10}$

Anthropogenic sources related to production, transfer, storage and refining of petroleum release NAH which are predominantly linear, branched and cyclic alkanes. ${ }^{11}$ Hydrocarbons derived from burning petroleum by-products are predominantly of a different nature. ${ }^{12}$ 
The low water solubility of hydrocarbons favors adsorption on suspended matter and consequent removal to bottom sediments by means of flocculation and precipitation. ${ }^{13-15}$ Once in the sediments, the fate of hydrocarbons depends on mechanisms of resuspension, degradation and benthic recycling. Although such processes may alter historical records in dated sediments there are indications of an increasing anthropogenic hydrocarbon flux to sediments as consequence of industrialization, urban development and fossil fuel consumption. ${ }^{16}$

Some petroleum derived hydrocarbons which are toxic to marine plants and animals may persist for long periods of time once released in the environment. Investigation on hydrocarbons sources and fate are thus very useful to evaluate environmental contamination and develop strategies for control and protection of coastal ecosystems. In the last decades numerous studies carried out in coastal estuarine areas evidenced the complex mixture of origins and sources of hydrocarbons present in surface marine sediment. ${ }^{6,10,17-21}$ Although the knowledge of hydrocarbon contamination in the Brazilian coastal zone is extremely important to preserve ecological resources and human health, few studies have been conducted on the fate of hydrocarbons in the vast coastal area of Brazil. ${ }^{22-31}$ Also, little is known about the performance of the several indicative indexes found in the specialized literature to distinguish hydrocarbon origin and sources in tropical coastal regions.
The present paper reports data on non-aromatic hydrocarbons in surface marine sediments collected in Ilha Grande and Sepetiba Bays. Sixteen sediment samples were collected and analyzed for non-aromatic hydrocarbons focusing on $n$-alkanes, isoprenoid hydrocarbons, alkenes and hopanes. The goal of the research work was to search for information on the assembly and nature of NAH in the area and for indications of petroleum contamination.

\section{Material and Methods}

\section{Study area}

Ilha Grande and Sepetiba Bays are located in the southern edge of the State of Rio de Janeiro. They are important tropical estuarine systems whose ecological wealth and rare natural beauty stimulated fisheries activities, national and international tourism (Figure 1). The main municipalities bordering the bays are those of Rio de Janeiro, Itaguaí, Mangaratiba, Angra dos Reis and Parati. These bays are surrounded by chains of forested mountains and there are 365 islands scattered in the marine area.

Sepetiba Bay is a partially mixed estuary with an area of $450 \mathrm{~km}^{2}$ and a maximum depth around $20 \mathrm{~m}$. The estimated population in the $2,400 \mathrm{~km}^{2}$ of drainage basin is of 1.7 million inhabitants. Guandu, Mazomba, Cação and Piraquê Rivers and the São Francisco Channel provide 95\% of the fresh water input to the bay. These water streams are

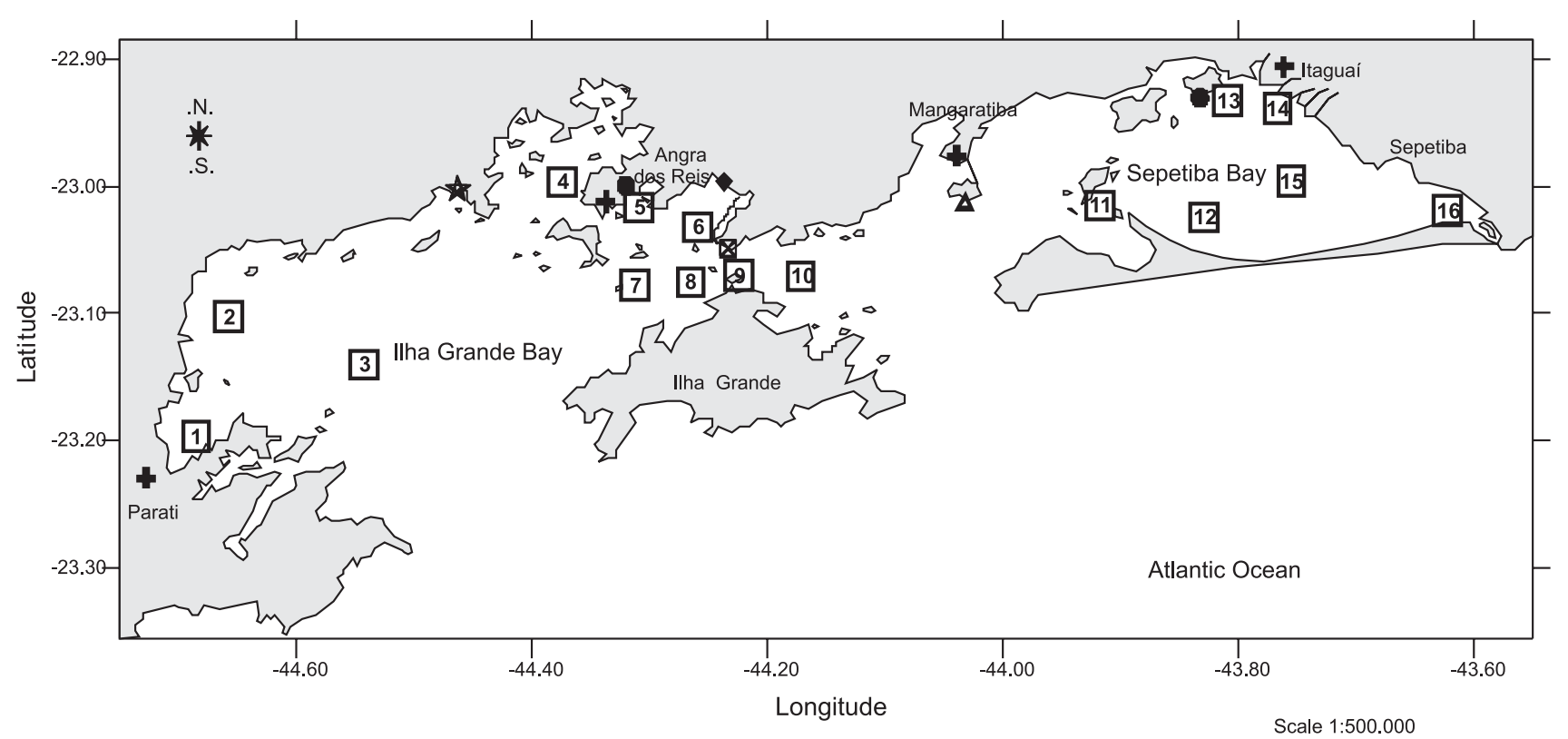

unicipality $\quad$ Nuclear Power Station

Harbour

Figure 1. Sampling stations at Ilha Grande and Sepetiba Bays, Rio de Janeiro, Brazil. 
severely contaminated by sanitary effluents and industrial discharges from chemical, pharmaceutical, steel mill, metallurgic, tanning and food plants. ${ }^{32,33}$ Ilha Grande Bay is served by a smaller drainage basin with $757 \mathrm{~km}^{2}$ and the maximum depth in the bay central channel is around $55 \mathrm{~m}$. Population in the basin is estimated around 160,000 inhabitants. This bay strongly influenced by oceanic waters houses several smaller embayments such as the Ribeira and Jacuacanga.

In both Sepetiba and Angra dos Reis Bays there are intensive maritime activities related to shipyards; in addition a petroleum terminal, an ore terminal, two harbors and two nuclear power stations are found in the region. ${ }^{34}$

Urban and industrial development in the region led to increasing inputs of raw sanitary effluent, trace metals and petroleum hydrocarbons to the bays. The existing information on the presence and levels of organic pollutants is very limited. ${ }^{35}$ Most scientific research conducted in this region was focused on trace metal contamination in mangroves and sediments of Sepetiba Bay. ${ }^{36-38}$

\section{Sample collection}

Sixteen surface sediment samples were collected at various stations in the near of urban centers, industrialized areas, harbors and in rather pristine areas (Figure 1 and Table 1). The selection of sampling location was based on the distribution of fine grain sediments (G. Dias, private communication).

A properly designed stainless steel Van Veen sampler was used, allowing recovery of undisturbed surface sediment. The first centimeter of sediment was scraped off using a stainless steel spatula and kept thereafter frozen in clean aluminum containers at $-20^{\circ} \mathrm{C}$.

\section{Extraction and analysis of hydrocarbons}

Sediments were freeze-dried, pulverized and sieved in stainless steel sieves of $1 \mathrm{~mm}^{2}$ mesh size. Sediments were spiked with $n-\mathrm{C}_{24} \mathrm{~d}_{50}$ as internal standard before extraction using 5 min sonication followed by reflux over $2 \mathrm{~h}$ at $45^{\circ} \mathrm{C}$ with a mixture of $\mathrm{CH}_{2} \mathrm{Cl}_{2} / \mathrm{CH}_{3} \mathrm{OH}(3: 1, \mathrm{v} / \mathrm{v})$, and again $5 \mathrm{~min}$ sonication. The extract was filtered in syntherized glass and then rotary evaporated. Water was eliminated by adding $2 \mathrm{~g}$ of anhydrous $\mathrm{MgSO}_{4}$. After filtration and washings with dichloromethane the extract was again rotary evaporated and treated under $\mathrm{N}_{2}$ flow. The dried extract was diluted in $5 \mathrm{~mL} \mathrm{CH}_{2} \mathrm{Cl}_{2}$ and transferred to a glass column fitted with colloidal copper for sulfur elimination. The extract was concentrated in a Büchi evaporator at low temperature $\left(<28{ }^{\circ} \mathrm{C}\right)$, and stored at $-18^{\circ} \mathrm{C}$.

Extract fractionation was performed in a glass column ( $9 \mathrm{~cm}$ length; $0.83 \mathrm{~cm}$ i.d.) slurry filled with $2 \mathrm{~g}$ of partially deactivated silica gel (Merck G 60). Seven fractions were obtained using the elution protocol given in. ${ }^{39}$ The first fraction, eluted by $6.5 \mathrm{~mL}$ of $\mathrm{n}$-hexane contained the non-aromatic hydrocarbons. Other fractions containing polycyclic aromatic hydrocarbons, wax esters, ketones, aldehydes, esters, alcohols, sterols and polar compounds were recovered for further analysis not reported here.

Table 1. Sampling location and ancillary data

\begin{tabular}{|c|c|c|c|c|c|c|}
\hline Station & Latitude / S & Longitude / W & Depth / m & TOC / \% & Carbonate / \% & Grain Size \\
\hline 1 & $03^{\circ} 11^{\prime} 80^{\prime \prime}$ & $44^{\circ} 41^{\prime} 12^{\prime \prime}$ & 2.5 & 1.64 & 8.51 & Silt \\
\hline 2 & $23^{\circ} 06^{\prime} 15^{\prime \prime}$ & $44^{\circ} 39^{\prime} 48^{\prime \prime}$ & 7.0 & 2.19 & 8.69 & Silt \\
\hline 3 & $23^{\circ} 08^{\prime} 44^{\prime \prime}$ & $44^{\circ} 32^{\prime} 60^{\prime \prime}$ & 24.8 & 0.21 & 7.42 & Fine Sand \\
\hline 4 & $22^{\circ} 59^{\prime} 81^{\prime \prime}$ & $44^{\circ} 22^{\prime} 50^{\prime \prime}$ & 15.2 & 1.15 & 8.55 & Silt \\
\hline 5 & $23^{\circ} 01^{\prime} 03^{\prime \prime}$ & $44^{\circ} 18^{\prime} 60^{\prime \prime}$ & 10.9 & 0.91 & 8.62 & Silt \\
\hline 6 & $23^{\circ} 01^{\prime} 95^{\prime \prime}$ & $44^{\circ} 15^{\prime} 60^{\prime \prime}$ & 16.4 & 0.95 & 10.73 & Silt \\
\hline 7 & $23^{\circ} 04^{\prime} 67^{\prime \prime}$ & $44^{\circ} 18^{\prime} 80^{\prime \prime}$ & 25.5 & 1.34 & 13.23 & Silt \\
\hline 8 & $23^{\circ} 04^{\prime} 54^{\prime \prime}$ & $44^{\circ} 15^{\prime} 52^{\prime \prime}$ & 32.7 & 0.63 & 88.85 & Silt \\
\hline 9 & $23^{\circ} 04^{\prime} 23^{\prime \prime}$ & $44^{\circ} 14^{\prime} 23^{\prime \prime}$ & 48.5 & 1.70 & 25.87 & Silt \\
\hline 10 & $23^{\circ} 04^{\prime} 25^{\prime \prime}$ & $44^{\circ} 10^{\prime} 33^{\prime \prime}$ & 21.8 & 0.40 & 17.30 & Medium Sand \\
\hline 11 & $23^{\circ} 00^{\prime} 91^{\prime \prime}$ & $43^{\circ} 55^{\prime} 10^{\prime \prime}$ & 12.0 & 0.45 & 16.96 & Medium Sand \\
\hline 12 & $23^{\circ} 01^{\prime} 49^{\prime \prime}$ & $43^{\circ} 49^{\prime} 79^{\prime \prime}$ & 10.0 & 1.00 & 6.46 & Silt \\
\hline 13 & $22^{\circ} 55^{\prime} 99^{\prime \prime}$ & $43^{\circ} 47^{\prime} 26^{\prime \prime}$ & 0.8 & 0.94 & 3.17 & Silt \\
\hline 14 & $22^{\circ} 56^{\prime} 23^{\prime \prime}$ & $43^{\circ} 46^{\prime} 42^{\prime \prime}$ & 1.1 & 1.84 & 4.88 & Silt \\
\hline 15 & $22^{\circ} 59^{\prime} 77^{\prime \prime}$ & $43^{\circ} 45^{\prime} 35^{\prime \prime}$ & 5.5 & 1.10 & 4.14 & Silt \\
\hline 16 & $23^{\circ} 01^{\prime} 14^{\prime \prime}$ & $43^{\circ} 37^{\prime} 40^{\prime \prime}$ & 0.8 & 0.90 & 6.14 & Silt \\
\hline
\end{tabular}


Analytical determinations were carried out by GC-FID and GC-MS. A Delsi DI 200 gas chromatograph equipped with a Ross-type injector and a flame ionization detector was used for GC determinations. The column used was a $50 \mathrm{~m}$ long, $0.32 \mathrm{~mm}$ i.d. fused silica capillary, coated with a film of CP-Sil-8, $0.25 \mu \mathrm{m}$ thick. Helium was the carrier gas (flow: $15 \mathrm{~mL} \mathrm{~min}^{-1}$ ) and the following temperature program was employed: from 80 to $300{ }^{\circ} \mathrm{C}$ at a rate of $2{ }^{\circ} \mathrm{C} \mathrm{min}-1$, and hold at $300{ }^{\circ} \mathrm{C}$ for $30 \mathrm{~min}$. The injector and detector temperatures were at $250{ }^{\circ} \mathrm{C}$ and $320^{\circ} \mathrm{C}$, respectively.

Quantifications were based on the calibrated flame ionization response to internal standards using an integrator, model APEX. The yield and reproducibility of the entire analytical scheme were evaluated through internal standard added in the original extract. Yield $(n=16)$ and reproducibility $(n=4)$ were as follows: $92 \pm 7 \%$ and $4.6 \%$ for $n-\mathrm{C}_{24} \mathrm{~d}_{50}$.

GC-MS analyses were performed for compound identification (hopanes and triterpanes) in a 3400 Varian gas chromatograph fitted with an on-column injector and coupled to an Saturn Varian ion trap mass spectrometer. The used column was a J\&W DB-5 $30 \mathrm{~m}$ long, $0.25 \mathrm{~mm}$ i.d. fused silica capillary with $0.25 \mu \mathrm{m}$ film thickness. The following temperature program was employed: $60^{\circ} \mathrm{C}$ for $3 \mathrm{~min}$, ramping from $60^{\circ} \mathrm{C}$ to $70^{\circ} \mathrm{C}$ at a rate of $25^{\circ} \mathrm{C} \mathrm{min}^{-1}$ and 70 to $300{ }^{\circ} \mathrm{C}$ at a rate of $2^{\circ} \mathrm{C} \mathrm{min}^{-1}$. The temperature of the detector was adjusted at $270{ }^{\circ} \mathrm{C}$. The mass spectrometer was scanned from 40 to $600 \mathrm{amu}$ at 0.6 scan per second. The electron energy was $70 \mathrm{eV}$.

The identification of compounds was based on comparison of $\mathrm{GC}$ retention times with those of external standards, $\mathrm{n}$-alkanes from $\mathrm{C}_{10}$ to $\mathrm{C}_{35}$, and mass spectra of authentic standards.

Precautions were taken to avoid contamination by cleaning glassware, Teflon, aluminum and stainless steel materials with Milli-Q water, heating during $8 \mathrm{~h}$ at $450{ }^{\circ} \mathrm{C}$ (unless for Teflon) and final washing with distilled $\mathrm{CH}_{3} \mathrm{OH}$ and $\mathrm{CH}_{2} \mathrm{Cl}_{2} \cdot \mathrm{CH}_{3} \mathrm{OH}$ and $\mathrm{CH}_{2} \mathrm{Cl}_{2}$ used as reagents were bi-distilled; magnesium sulfate and cotton were Soxhlet extracted with $\mathrm{CH}_{2} \mathrm{Cl}_{2}$ and dried during $24 \mathrm{~h}$ at $110{ }^{\circ} \mathrm{C}$; silica gel was Soxhlet extracted with $\mathrm{CH}_{2} \mathrm{Cl}_{2}$, dried at $225^{\circ} \mathrm{C}$ over $72 \mathrm{~h}$ and deactivated with Milli-Q water (5\%) during $72 \mathrm{~h}$ under shaking.

Organic carbon was determined in all samples in a TOC Dohrmann DC-190 Analyser. Grain size, water and carbonate content were obtained according to the procedure described by Folk and Ward. ${ }^{40}$

\section{Results and Discussion}

Table 1 summarizes the bulk properties obtained for the 16 samples. Based on the particle size distribution of the sediments, two sample groups may be defined: one rich in silt, with organic carbon being $>0.63 \%$ (dry weight sediment), whereas the other is composed either of fine $62-125 \mu \mathrm{m}$ sand (at station 3) or medium size 250-500 $\mu \mathrm{m}$ sand (stations 10 and 11 ) and is low in organic carbon $<0.45 \%$.

The greater organic carbon values were found: $(i)$ at stations 1 and 2 which are nearer to the coast line in the western part of the Ilha Grande Bay, an area of low hydrodynamics that receives inputs from mangroves and from the Parati River; (ii) at station 14 located at the mouth of the sewage contaminated Guandu river; and (iii) at station 9, where the bottom topography and presence of a depression may favor particle settling.

\section{Total hydrocarbons}

Total Hydrocarbon concentrations (TH - resolved and non-resolved aliphatic and aromatic hydrocarbons not reported here) vary from $4.75 \mu \mathrm{g} \mathrm{g}^{-1}$ to $233.79 \mu \mathrm{g} \mathrm{g}^{-1}$, whereas resolved NAH are between $0.49 \mu \mathrm{g} \mathrm{g}^{-1}$ and $14.10 \mu \mathrm{g} \mathrm{g}^{-1}$ (Table 2). Urban and industrial inputs derived from surface drainage and contributions from several contaminated rivers discharging in the area (Guandu, Guarda, Piraquê and São Francisco) are responsible for the highest concentrations found in station 14. Lowest TH concentrations ( $4.75 \mu \mathrm{g} \mathrm{g}^{-1}$ to $\left.13.86 \mu \mathrm{g} \mathrm{g}^{-1}\right)$ are found in the areas of sandy and carbonate rich sediments (stations 3, 8, 10 and 11).

\section{Non-aromatic hydrocarbons}

Total NAH concentration varies between $2.50 \mu \mathrm{g} \mathrm{g} \mathrm{g}^{-1}$ and $193.84 \mu \mathrm{g} \mathrm{g}^{-1}$. The lowest values appeared in sandy stations $(03,10$ and 11$)$ and in station 8 (high carbonate content), and the highest concentration were found in stations 13 and 14.

Normalization of hydrocarbon concentration to TOC (total organic carbon) shows features of concentration distribution, which were masked due to the dilution effect of coarse sediment fractions (see Figures 2 and 3). For instance, there is a substantive contribution of NAH to the carbon pool in stations 8, 10 and 11 unnoticed before normalization.

The poor linear correlation between NAH and TOC content $(r=0.455 ; p<0.05)$ indicates that fine inorganic particles may play a significant role in the transport of hydrocarbons to the sediments. Differences in degradation kinetics may also lead to such a lack of correlation. Indeed, the excellent correlation found between resolved NAH and TOC $(r=0.842, p<0.05)$ suggests different degradation kinetics for UCM components and for the bulk of organic carbon. In the plot of resolved NAH versus TOC values 
Table 2. Concentration of total and resolved non-aromatic hydrocarbons, and related indexes in sediment samples

\begin{tabular}{|c|c|c|c|c|c|c|c|c|}
\hline Station & $\begin{array}{c}\mathrm{TH} / \\
\left(\mu \mathrm{g} \mathrm{g}^{-1}\right)\end{array}$ & $\begin{array}{l}\text { NAH/ } \\
\left(\mu g^{-1}\right)\end{array}$ & $\begin{array}{c}\mathrm{NAH} / \\
\left(\mu \mathrm{g} \mathrm{g}^{-1} \mathrm{TOC}\right)\end{array}$ & $\begin{array}{l}\mathrm{NAH}_{\mathrm{res}} / \\
\left(\mu \mathrm{g} \mathrm{g}^{-1}\right)\end{array}$ & $\begin{array}{l}n \text {-Alk/ } \\
\left(\mu \mathrm{g} \mathrm{g}^{-1}\right)\end{array}$ & $\begin{array}{c}n \text {-Alk/ } \\
\left(\mu \mathrm{g} \mathrm{g}^{-1} \mathrm{TOC}\right)\end{array}$ & $\begin{array}{c}n \text {-Alk-Ter/ } \\
(n-\mathrm{Alk} \%)\end{array}$ & $\begin{array}{c}\text { Ratio } \\
n-\mathrm{C}_{17} / n-\mathrm{C}_{29}\end{array}$ \\
\hline 1 & 25.64 & 16.86 & $1,030.29$ & 6.07 & 3.63 & 221.70 & $54.0 \%$ & 0.02 \\
\hline 2 & 31.79 & 19.65 & 897.42 & 9.20 & 6.11 & 278.95 & $51.7 \%$ & 0.01 \\
\hline 3 & 4.75 & 2.50 & $1,167.10$ & 0.49 & 0.20 & 94.86 & $44.3 \%$ & 0.13 \\
\hline 4 & 24.21 & 16.90 & $1,471.73$ & 4.34 & 2.11 & 183.88 & $50.1 \%$ & 0.04 \\
\hline 5 & 28.26 & 21.67 & $2,390.23$ & 3.10 & 1.20 & 132.36 & $48.8 \%$ & 0.05 \\
\hline 6 & 31.62 & 22.96 & $2,422.80$ & 4.04 & 1.69 & 178.52 & $44.0 \%$ & 0.07 \\
\hline 7 & 35.38 & 26.21 & $1,950.40$ & 5.63 & 2.78 & 206.55 & $48.4 \%$ & 0.07 \\
\hline 8 & 13.86 & 9.64 & $1,540.52$ & 2.10 & 0.86 & 138.24 & $42.8 \%$ & 0.10 \\
\hline 9 & 49.32 & 32.66 & $1,920.23$ & 12,05 & 8.20 & 482.25 & $33.1 \%$ & 0.04 \\
\hline 10 & 11.37 & 9.60 & $2,406.02$ & 0.73 & 0.35 & 87.99 & $39.6 \%$ & 0.13 \\
\hline 11 & 11.84 & 10.14 & $2,276.50$ & 0.95 & 0.34 & 75.92 & $34.6 \%$ & 0.29 \\
\hline 12 & 45.03 & 35.71 & $3,556.61$ & 4.43 & 1.69 & 167.93 & $49.0 \%$ & 0.07 \\
\hline 13 & 63.38 & 45.27 & $4,837.26$ & 8.56 & 5.92 & 632.33 & $48.0 \%$ & 0.05 \\
\hline 14 & 233.79 & 193.84 & $10,557.90$ & 14.10 & 8.56 & 466.12 & $38.7 \%$ & 0.32 \\
\hline 15 & 33.07 & 25.98 & $2,362.26$ & 3.24 & 1.65 & 150.18 & $40.5 \%$ & 0.03 \\
\hline 16 & 18.47 & 11.96 & $1,332.12$ & 3.56 & 2.31 & 257.04 & $44.0 \%$ & 0.03 \\
\hline
\end{tabular}

TH: total hydrocarbon; NAH: total non-aromatic hydrocarbon; $\mathrm{NAH}_{\mathrm{res}}$ : resolved non-aromatic hydrocarbon; TOC: total organic carbon; $n$-Alk: $n$-alkanes $\left(\sum n-\mathrm{C}_{14}\right.$ to $\left.n-\mathrm{C}_{36}\right) ; n$-Alk-Ter: $\sum n-\mathrm{C}_{27}, n-\mathrm{C}_{29}$ and $n-\mathrm{C}_{31}$.

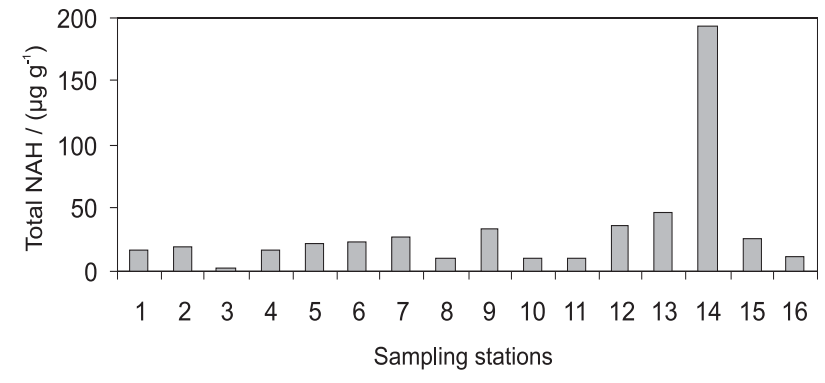

Figure 2. Total non-aromatic hydrocarbons (NAH) in surface sediments from several stations at Ilha Grande and Sepetiba Bays.

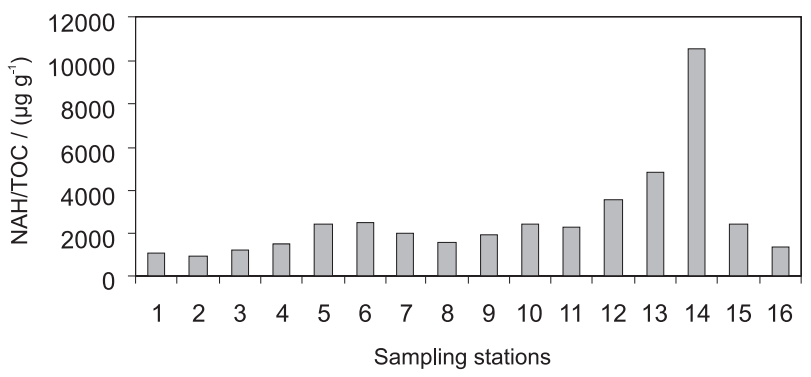

Figure 3. Non-aromatic hydrocarbons (NAH) normalized for the organic carbon content (TOC) in surface sediments at several stations in Ilha Grande and Sepetiba Bays.

from station 9, 13 and 14 are far above the average line and when these values are removed a correlation coefficient of $0.98(p<0.05)$ is obtained for a curve with an intercept close to zero. Such observations indicate that the resolved NAH fraction in these three stations was either more recently introduced than the bulk of the organic material or was transferred to the sediments attached to other phases.

The average values obtained for total NAH are above the expected threshold for unpolluted estuarine sediments which are in the range of a few $\mathrm{ng} \mathrm{g}^{-1}$ to $10 \mu \mathrm{g} \mathrm{g}^{-1}$ of sediment or below $50 \mu \mathrm{g} \mathrm{g}^{-1}$ of TOC. ${ }^{6}$ However, Bouloubassi and Saliot report that hydrocarbon concentration may reach values as high as $100 \mu \mathrm{g} \mathrm{g}^{-1}$ in unpolluted sediments with high organic content due to contributions from biogenic sources. ${ }^{41}$

\section{Alkanes}

The contribution of $n$-alkanes to total NAH concentration lies between $36 \%$ and $69 \%$, with an average value of $51.4 \pm 11.7 \%$ (Table 2). $n$-Alkanes and TOC content are significantly correlated $(\mathrm{r}=0.810)$ suggesting combined deposition and similar decomposition kinetics (Figures 4 and 5). Concentrations observed in sediments of Sepetiba

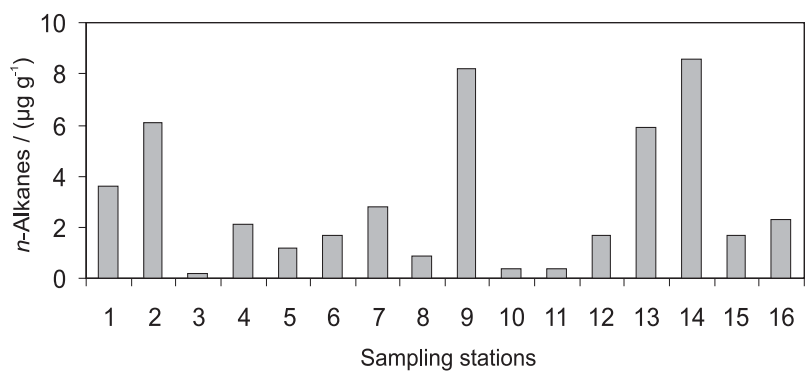

Figure 4. $n$-Alkane concentration in surface sediments at several stations in Ilha Grande and Sepetiba Bays. 


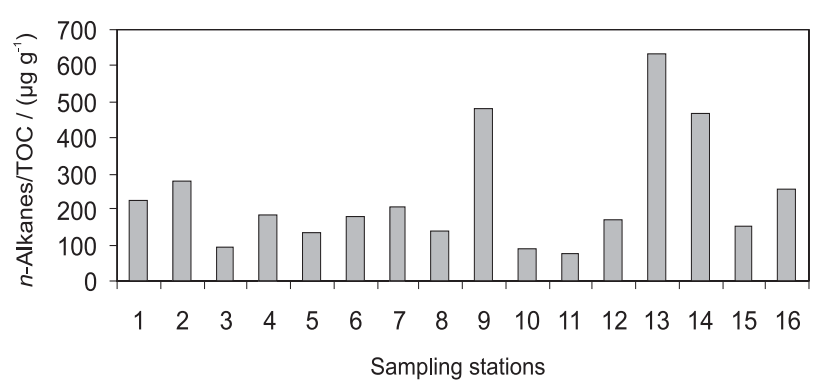

Figure 5. $n$-Alkane concentration in surface sediments at several stations in Ilha Grande and Sepetiba Bays.

and Ilha Grande Bays are similar to those reported for other Brazilian estuarine regions, like Cananéia and São Sebastião in São Paulo, Guanabara Bay in Rio de Janeiro

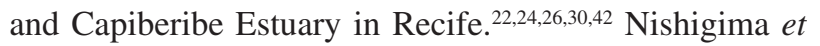
$a l .{ }^{28}$ report total n-alkanes in range of 4.37 to $157.90 \mu \mathrm{g} \mathrm{g}^{-1}$ for Cananéia, a region presenting very low anthropogenic activity and surrounded by dense mangrove vegetation.

In most samples the $n$-alkanes distribution pattern is unimodal with predominance of odd carbon number $n$-alkanes and maximum values at $n-\mathrm{C}_{29}$ and $n-\mathrm{C}_{31}$. However stations 11 and 14 show a bimodal distribution with maximum values at $n-\mathrm{C}_{17}$ and $n-\mathrm{C}_{19}$ and at $n-\mathrm{C}_{29}$ and $n$ - $\mathrm{C}_{31}$, while station 9 shows a uniform peak distribution in which odd or even carbon number predominance is not observed (Figure 6). The $\mathrm{C}_{21} n$-alkane was not quantified because of co-elution with a highly branched isoprenoid ( $\mathrm{HBI} \mathrm{C}_{25} \mathrm{H}_{46}$ ).

Except for station 9, the dominance of the $n-\mathrm{C}_{29}$ and $n-\mathrm{C}_{31}$ homologs is a common pattern that results from higher plant waxes and, thus, reveals the occurrence of terrestrial inputs to the study area. ${ }^{43}$ In station 09 (48.5 meters depth) the predominance of $n-\mathrm{C}_{26}$ indicates that marine pelagic bacteria are important sources of $n$-alkanes. ${ }^{18}$

The sum of the most abundant $n$-alkanes related to biogenic terrestrial sources $\left(\mathrm{C}_{27}, \mathrm{C}_{29}\right.$ and $\mathrm{C}_{31} ; n$-Alk-Ter) account for $33.12 \%$ (station 09) to $53.96 \%$ (station 01) of the total $n$-alkanes (Table 2). Among the short-chain $\left(<\mathrm{C}_{20}\right) n$-alkanes the general predominance of $n-\mathrm{C}_{17}$ and $n-\mathrm{C}_{19}$ show additional contribution from marine bacteria, phytoplankton and seaweeds. ${ }^{6,7}$

The ratio between $n-\mathrm{C}_{17}$ and $n-\mathrm{C}_{29}$ has been used to evaluate the relative importance of marine and terrestrial contributions to the sediments. ${ }^{41}$ The current results show a general trend to an increasing $n-\mathrm{C}_{17}$ (indicative of autochthonous origin) $/ n-\mathrm{C}_{29}$ ratio from the coastal to the offshore zone. In station 14 the high value found of 0.32 was an exception possibly due to the local effects of sewage derived nutrients on primary production rates (Table 2). According to Prahl and Carpenter, the preferential remineralization of marine organic matter in the water
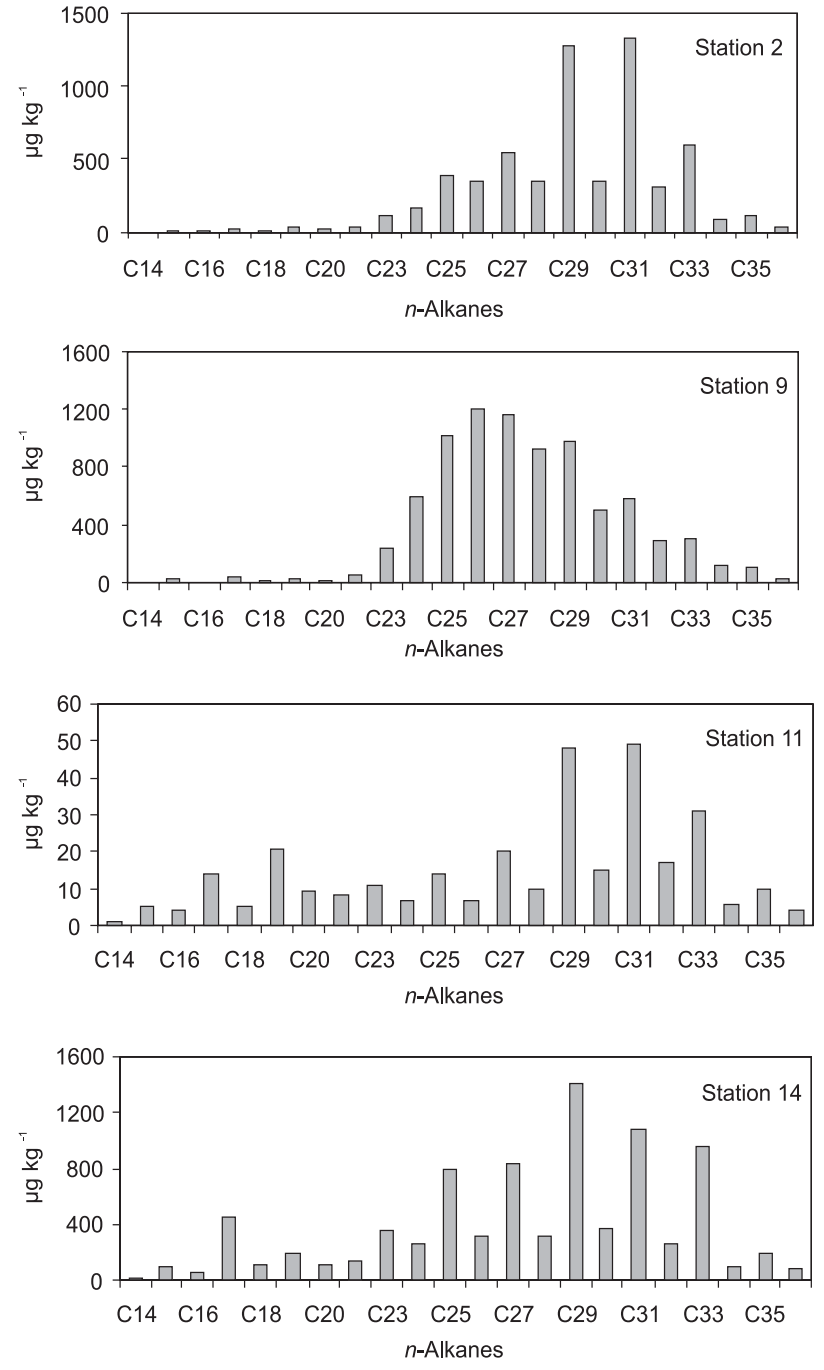

Figure 6. Examples of $n$-alkane distribution patterns in surface sediments (stations 2, 9, 11 and 14) in Ilha Grande and Sepetiba Bays.

column, as compared to terrestrial organic material, and at the sediment-water interface alters the $n-\mathrm{C}_{17} / n-\mathrm{C}_{29}$ ratio and may lead to overestimating contributions from watershed plants. ${ }^{44}$ The ratio $\mathrm{C}_{17} / \mathrm{C}_{18}$ between 3.5 and 5 for stations $6,8,9,10$ and 14 indicates those sites as of higher marine organic matter accumulation amongst all other stations $\left(2.1>\mathrm{C}_{17} / \mathrm{C}_{18}<3.0\right){ }^{45}$

The Carbon Preference Index (CPI) showed in Figure 7 was calculated for three different carbon number ranges usually attributed to substances derived from the following sources: marine phytoplankton and bacteria $\left(n-\mathrm{C}_{16}\right.$ to $\left.n-\mathrm{C}_{20}\right)$, seaweed detritus $\left(n-\mathrm{C}_{22}\right.$ to $\left.n-\mathrm{C}_{26}\right)$, and higher plant waxes $\left(n-\mathrm{C}_{26}\right.$ to $\left.n-\mathrm{C}_{36}\right)$.

CPI values higher than 4.0 in the range of $n-\mathrm{C}_{16}$ to $n-\mathrm{C}_{20}$ strengthen the previous indications of plankton and bacteria predominance in stations 8 and 9; in station $12 \mathrm{CPI}_{16-20}$ and $\mathrm{CPI}_{26-36}$ values $>4.0$ suggest equal contributions from marine and terrestrial biogenic sources; and in station 

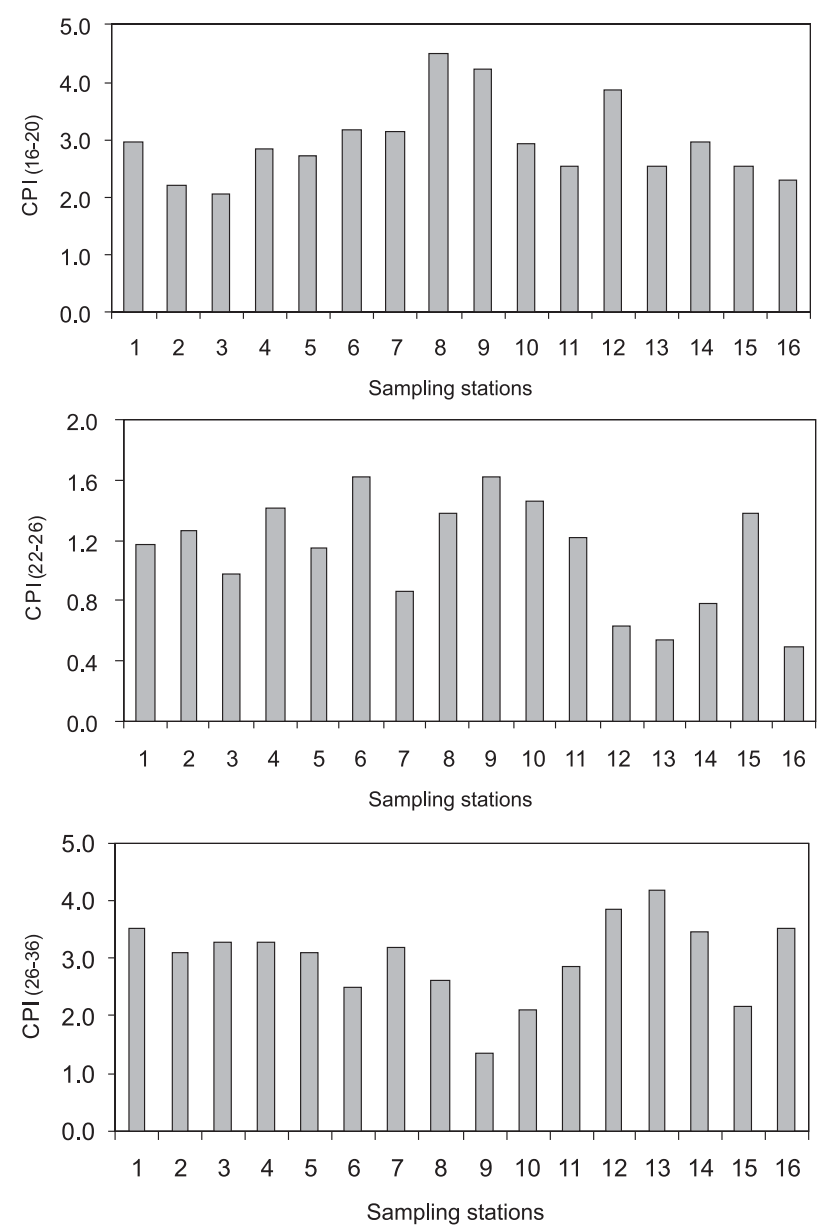

Figure 7. Carbon Preference Index obtained for surface sediments from several stations in Ilha Grand and Sepetiba Bays.

$13, \mathrm{CPI}_{26-36}$ characterizes the predominance of terrestrial sources. ${ }^{46}$

In the other sampling stations values between 1.0 and 4.0 indicate presence of $n$-alkanes from mixed biogenic and fossil sources. The influence on the CPI index of bacterial sources with no noticeable even/odd carbon preference or of degraded $n$-alkanes from terrestrial sources cannot be ruled out. This is, especially true in stations 1 and 2 located in the western sector of Ilha Grande Bay where significant pollutant sources do not exist.

The odd/even predominance index $\left(\mathrm{OEPI}=\left\{\left[\left(\mathrm{C}_{n}+\right.\right.\right.\right.$ $\left.\left.\left.\left.6 \mathrm{C}_{n+2}+\mathrm{C}_{n+4}\right) /\left(4 \mathrm{C}_{n+1}+4 \mathrm{C}_{n+4}\right)\right]^{-1}\right\}^{n+1}\right)$ proposed by Scalan and Smith show similar information as the CPI index and was used here to put in evidence similarities among sampling stations (Figure 8): ${ }^{47}$

High OEPI values (3.2 to 6.8) in the range $n-\mathrm{C}_{16}$ to $n-\mathrm{C}_{18}$ confirm the predominance of marine biogenic material, in stations 8,9 and 10 . In the range $n-\mathrm{C}_{24}$ to $n-\mathrm{C}_{34}$ lower OEPI values (1.0 to 3.3 ) may be ascribed to additional contribution from anthropogenic sources. These sampling stations are situated in an area subjected to strong marine

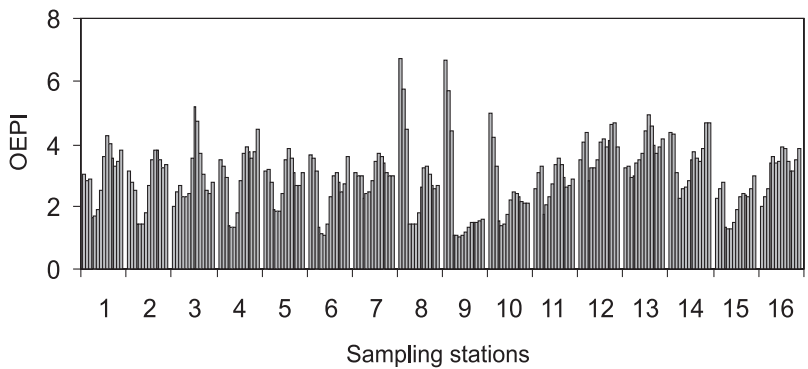

Figure 8. OEPI index in the carbon range from $n-\mathrm{C}_{16}$ to $n-\mathrm{C}_{18}$ and $n-\mathrm{C}_{24}$ to $n-\mathrm{C}_{34}$.

currents in which sediments are sandy and/or calcareous with low organic content. Oxic conditions may be expected in sediments with such properties. The outstanding $\mathrm{Pr} / \mathrm{Ph}$ ratios (see below for further discussion) found in these station also point out the presence of marine biogenic material and oxic conditions.

Stations 3 (OEPI 2.0 to 5.2) and 13 (OEPI 2.9 to 4.9) located in the center of the Ilha Grande and Sepetiba Bays, respectively, show an unimodal OEPI distribution pattern with maximum values in the range $n-\mathrm{C}_{27}-n-\mathrm{C}_{30}$ reflecting predominance of homologs originated from terrestrial higher plants.

In stations 1, 2, 4, 5, 6, 7, 11, 12, 14, and 15 OEPI index show a bimodal distribution pattern with high values in both ranges of $n-\mathrm{C}_{16}-n-\mathrm{C}_{18}$ (OEPI 2.3 to 4.4 ), and $n-\mathrm{C}_{28}-n-\mathrm{C}_{34}$ (OEPI 1.9 to 4.9 ). This feature indicates even inputs of terrestrial, marine and fossil carbon sources.

Station 16 under influence of a dense mangrove area, shows equivalent values for the OEPI index in the range $n-\mathrm{C}_{24}$ to $n-\mathrm{C}_{34}\left(\mathrm{OEPI}_{24-34} 3.1\right.$ to 3.9$)$, characterizing the dominance of a large spectrum of terrestrial biogenic sources in this area.

The concentrations of the isoprenoid alkanes pristane $(\mathrm{Pr})$ and phytane $(\mathrm{Ph})$ in the sediment varies from 1 to $180 \mathrm{ng} \mathrm{g}^{-1}$ and are linearly correlated $(\mathrm{r}=0.957 ; \mathrm{p}<0.05)$. Correlation between these compounds and $n$-alkanes is less important $(r=0.650)$ possibly due to provenance from different sources or distinct degradation process (Table 3).

$\mathrm{Pr} / \mathrm{Ph}$ ratio in uncontaminated sediments is higher than 1 and according to Steinhauer and Boehm usually between 3 and $5 .{ }^{48}$ Stations located in the western side of Ilha Grande Bay (stations 1 to 4) which are distant from major contamination sources as well as those in the contaminated Sepetiba Bay (stations 11 to 16) showed values below 2.0. In stations 13 and 15 the ratio was below 1 indicating presence of petroleum products. In the region between the land and Grande Island (5 to 10 ) $\mathrm{Pr} / \mathrm{Ph}$ values above 2.0 point out biogenic contributions and possibly predominance of oxic conditions in the local sediments. 
Table 3. Concentration of pristane, phytane, unresolved complex mixture and related indexes in sediment samples

\begin{tabular}{|c|c|c|c|c|c|c|c|}
\hline Station & $\operatorname{Pr} /\left(\mu \mathrm{g} \mathrm{kg}^{-1}\right)$ & $\mathrm{Ph} /\left(\mu \mathrm{gg}^{-1}\right)$ & $\mathrm{Pr} / \mathrm{Ph}$ & $n-\mathrm{C}_{17} / \mathrm{Pr}$ & $n-\mathrm{C}_{18} / \mathrm{Ph}$ & $\mathrm{UCM} /\left(\mu \mathrm{g} \mathrm{g}^{-1}\right)$ & $\mathrm{U} / \mathrm{R}$ \\
\hline 1 & 18 & 14 & 1.3 & 1.3 & 0.7 & 10.78 & 1.8 \\
\hline 2 & 11 & 9 & 1.2 & 1.7 & 1.0 & 10.45 & 1.1 \\
\hline 3 & 5 & 3 & 1.7 & 1.0 & 0.7 & 2.00 & 4.1 \\
\hline 4 & 9 & 5 & 1.8 & 1.9 & 1.2 & 12.56 & 2.9 \\
\hline 5 & 4 & 1 & 4.0 & 3.0 & 4.0 & 18.57 & 6.0 \\
\hline 6 & 11 & 3 & 3.7 & 1.9 & 2.0 & 18.92 & 4.7 \\
\hline 7 & 16 & 6 & 2.7 & 2.3 & 2.0 & 20.58 & 3.7 \\
\hline 8 & 20 & 2 & 10.0 & 0.8 & 1.5 & 7.54 & 3.6 \\
\hline 9 & 34 & 6 & 5.7 & 1.1 & 1.3 & 20.61 & 1.7 \\
\hline 10 & 4 & 1 & 4.0 & 1.8 & 2.0 & 8.86 & 12.1 \\
\hline 11 & 13 & 11 & 1.2 & 1.1 & 0.5 & 9.18 & 9.6 \\
\hline 12 & 8 & 6 & 1.3 & 3.1 & 1.2 & 31.28 & 7.1 \\
\hline 13 & 25 & 39 & 0.6 & 2.6 & 0.6 & 36.71 & 4.3 \\
\hline 14 & 180 & 112 & 1.6 & 2.5 & 1.0 & 179.74 & 12.7 \\
\hline 15 & 2 & 3 & 0.7 & 4.5 & 1.3 & 22.74 & 7.0 \\
\hline 16 & 10 & 8 & 1.3 & 1.3 & 0.8 & 8.40 & 2.4 \\
\hline
\end{tabular}

Pr: pristane; Ph: phytane; UCM: unresolved complex mixture; U/R: unresolved complex mixture/resolved NAH.

The $n-\mathrm{C}_{17} / \mathrm{Pr}$ and $n-\mathrm{C}_{18} / \mathrm{Ph}$ ratios also given under Table 3 , emphasize two different sediment groups: those found in station 5 (close to Angra dos Reis Harbor) and 12 to 15 (under influence of significant anthropogenic activities in the Sepetiba Bay) presenting one or both ratios above 2.5 , and those with ratios below 2.5 found in the rest of the sampling stations. Values greater than 2.5 for $n-\mathrm{C}_{17} / \mathrm{Pr}$ and $n-\mathrm{C}_{18} / \mathrm{Ph}$ indicate recent biogenic inputs and partially degraded petrogenic residues, respectively, while values below 2.5 point out the occurrence of degraded $n$-alkanes as a consequence of the microbial preference to degrade linear alkanes. ${ }^{49}$

\section{Unresolved Complex Mixture (UCM)}

The UCM concentrations represent from 53.2\% (03) to $92.7 \%$ (14) of the Total Non-Aromatic Hydrocarbon (Table 3). The lowest values are observed in the sandy and calcareous sediments $(3,8,10$ and 11), while the highest values are verified in sediments from Sepetiba Bay (12 to 15) that is strongly influenced by anthropogenic activities.

Station 14 presents the maximum observed UCM concentration equal to $179.74 \mu \mathrm{g} \mathrm{g}^{-1}$. This is 4.9 times greater than the second largest value found at station 13 (36.71 $\left.\mu \mathrm{g} \mathrm{g}^{-1}\right)$ that lies in the same region of station 14 . Such high values indicate a substantive local input of hydrocarbons associated to petroleum and by-products through the Guandu River and São Francisco Channel.

A unimodal UCM distributed between $n-\mathrm{C}_{18}$ and $n-\mathrm{C}_{35}$ and with a maximum value between $n-\mathrm{C}_{30}$ and $n-\mathrm{C}_{31}$ was found in most of the samples. Those are indications of residual petrogenic NAH in this molecular range.
In stations $01,03,11$, and $16 \mathrm{UCM}$ was bimodal featuring a second ramp in the range $n-\mathrm{C}_{16}$ to $n-\mathrm{C}_{22}$ and revealing the presence of low molecular weight $\mathrm{NAH}$, possibly originated from fuel oil and lubricants or from degraded plant detritus. ${ }^{17,50,51}$ From this group only in stations 3 and 11 the UCM/resolved NAH (U/R) ratio > 4 unambiguously indicates petrogenic contamination.

$\mathrm{U} / \mathrm{R}$ values higher than 4.0 were identified: in station 03 $(\mathrm{U} / \mathrm{R}=4.1)$, as already discussed above, located western of Ilha Grande Bay, in an area of intense tanker navigation and anchorage; in stations 05 (6.0) and 06 (4.7), at the entrance of Angra dos Reis and Jacuacanga Bays, close to urban, shipyard, and harbor activities; in station 10 (12.1) that lies in the navigation channel providing access to the petroleum terminal (TEBIG); and in stations 11 to 15 , in Sepetiba Bay, which are as already mentioned under influence of urban, industrial, and harbor activities.

\section{Olefins}

The linear mono-olefins $n-\mathrm{C}_{19: 1}, n-\mathrm{C}_{23: 1}, n-\mathrm{C}_{25: 1}$, and $n-\mathrm{C}_{27: 1}$ were present at low concentrations in most of the sediment samples possibly due to their low persistence in the environment. ${ }^{52}$ The polyolefins including the sum of highly branched isoprenoids (HBI) and squalene (see Figure 9) varied from $0.099 \mu \mathrm{g} \mathrm{g}^{-1}$ (03) to $1.387 \mu \mathrm{g} \mathrm{g}^{-1}$ (09) and represent $1.8 \%$ (station 13 ) to $38.0 \%$ (station 11) of the resolved NAH. The lowest concentrations of polyolefins occurred in stations 3, 10, 11 (sandy sediments) and 16 where total content of NAH was low. The lowest percentages of polyolefins related to the resolved NAH were observed in stations 13 and 14, under strong terrestrial and 
Table 4. Concentration of polyolefins and their percentage related to resolved NAH

\begin{tabular}{|c|c|c|c|c|c|c|}
\hline Station & $\begin{array}{l}\mathrm{HBI} \mathrm{C}_{20} \text { ' } \\
\mu \mathrm{g} \mathrm{g}^{-1}\end{array}$ & $\begin{array}{c}\mathrm{HBI} \mathrm{C} \mathrm{C}_{25} \text { I } \\
\mu \mathrm{g} \mathrm{g}^{-1}\end{array}$ & $\begin{array}{l}\mathrm{HBI} \mathrm{C}_{30} \text { ' } \\
\mu \mathrm{g} \mathrm{g}^{-1}\end{array}$ & $\begin{array}{l}\text { Squalene/ } \\
\mu \mathrm{g} \mathrm{g}^{-1}\end{array}$ & $\begin{array}{l}\text { Total Polyolefins/ } \\
\mu \mathrm{g} \mathrm{g}^{-1}\end{array}$ & $\begin{array}{c}\text { Total Polyolefins/ } \\
\text { Resolved NAH (\%) }\end{array}$ \\
\hline 1 & 0.087 & 0.304 & nd & 0.137 & 0.528 & 8.7 \\
\hline 2 & 0.054 & 0.702 & 0.011 & 0.186 & 0.953 & 10.4 \\
\hline 3 & 0.019 & 0.048 & 0.018 & 0.013 & 0.099 & 20.0 \\
\hline 4 & 0.032 & 0.325 & 0.102 & 0.058 & 0.518 & 11.9 \\
\hline 5 & 0.048 & 0.317 & 0.050 & 0.049 & 0.464 & 15.0 \\
\hline 6 & 0.067 & 0.484 & 0.080 & 0.062 & 0.693 & 17.2 \\
\hline 7 & 0.099 & 0.352 & 0.015 & nd & 0.466 & 8.3 \\
\hline 8 & 0.031 & 0.253 & 0.079 & 0.079 & 0.442 & 21.0 \\
\hline 9 & 0.031 & 0.857 & 0.353 & 0.146 & 1.387 & 11.5 \\
\hline 10 & 0.015 & 0.087 & 0.015 & 0.019 & 0.136 & 18.5 \\
\hline 11 & 0.020 & 0.309 & 0.009 & 0.025 & 0.362 & 38.0 \\
\hline 12 & 0.047 & 1.006 & 0.048 & 0.082 & 1.183 & 26.7 \\
\hline 13 & 0.021 & 0.071 & nd & 0.064 & 0.156 & 1.8 \\
\hline 14 & 0.246 & 0.176 & nd & 0.085 & 0.507 & 3.6 \\
\hline 15 & 0.049 & 0.611 & 0.020 & 0.031 & 0.711 & 21.9 \\
\hline 16 & 0.029 & 0.211 & 0.008 & 0.037 & 0.285 & 8.0 \\
\hline Average Value & 0.056 & 0.382 & 0.050 & 0.067 & 0.556 & 15.2 \\
\hline St. Deviation & \pm 0.056 & \pm 0.281 & \pm 0.087 & \pm 0.052 & \pm 0.363 & \pm 9.2 \\
\hline
\end{tabular}

HBI: highly branched isoprenoid compounds; nd: below the detection limit.

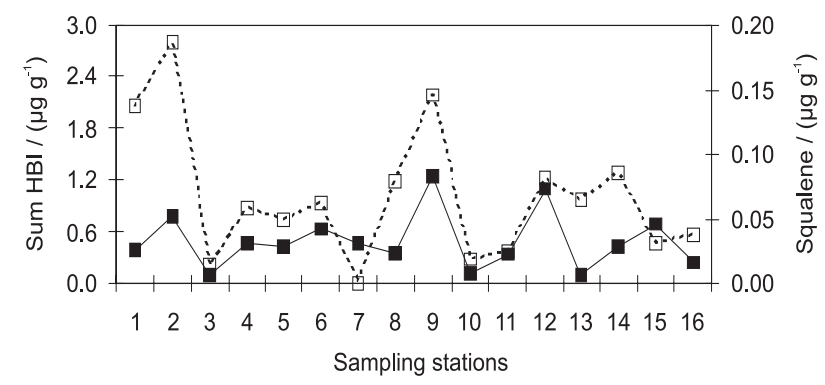

Figure 9. Highly branched isoprenoids (HBI) and squalene concentrations in surface sediments at several stations in Ilha Grande and Sepetiba Bays.

anthropogenic influence (Table 4) while other stations with HBI fractions above $17 \%$ receive substantive autochthonous biogenic inputs.

HBI $C_{20: 1}, C_{20: 2}, C_{25: 2}, C_{25: 3}, C_{25: 4}, C_{30: 4}, C_{30: 5}$, and $\mathrm{C}_{30: 6}$ were identified in the sediments, although $\mathrm{C}_{25}$ predominated in all samples, except at station 14, where HBI $\mathrm{C}_{20}$ probably associated to an algal source was dominant. ${ }^{53} \mathrm{HBI} \mathrm{C}_{25}$ and $\mathrm{C}_{30}$ are secondary metabolites that might be derived from diatoms in many contemporary marine environments; therefore they are markers of marine biogenic sources.

Squalene, a substance omnipresent in the eukaryotes and prokaryotes was found from below detection limit (station 7) to $40.9 \%$ (station 13) of the total polyolefins, with an average value of $13.8 \pm 9.6 \% .^{10}$

\section{Triterpanes}

Hopane series between $\mathrm{C}_{27}$ and $\mathrm{C}_{33}$ were observed in all samples, with the predominant configuration $17 \alpha(\mathrm{H}), 21 \beta(\mathrm{H})$, characteristic of a petrogenic origin. Stations 13 and 14 showed hopanoid series extending to $\mathrm{C}_{35}$, characterized by epimerization in $\mathrm{C} 22(\mathrm{~S}+\mathrm{R})$ of the homologs $\mathrm{C}_{31}$ to $\mathrm{C}_{35}$, typical from fossil origin (Figure 10). Due to difficulties in obtaining authentic standards quantification of individual hopanes was not made; however these compounds were relatively more significant in stations 13 and 14 which are the most impacted by terrestrial anthropogenic activities. The presence of these compounds in the sediments also indicates organic matter in advanced stage of degradation. ${ }^{51}$

The unsaturated triterpenoid diploptene, found in nearly all hopanoid-producing bacteria was present in lower proportions relative to the hopanes. Trisnorhop$17(21)$-ene $(17 \beta(H), 21 \beta(H))$ of recent biogenic origin, was generally observed in low proportions, except in station 16 where it appeared as dominant amongst all other identified polycyclic triterpenoids.

\section{Conclusions}

The analysis of non-aromatic hydrocarbons from 16 surface sediments collected in Sepetiba and Ilha Grande 


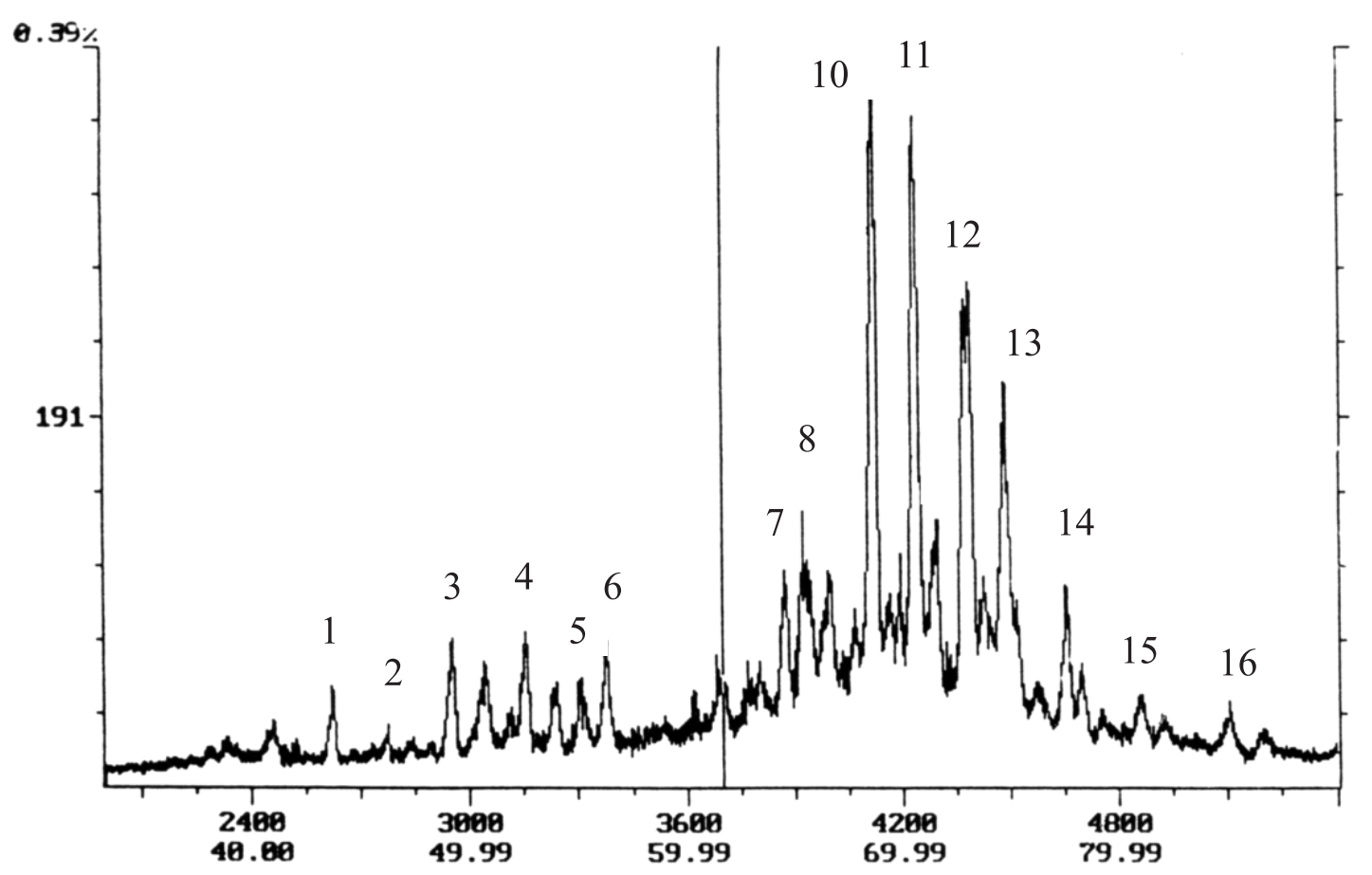

Figure 10. Ion chromatogram $(\mathrm{m} / \mathrm{z}, 191)$ determined in sediment sample from station $13.1-\mathrm{C}_{21} \mathrm{H}_{38}$ tricyclic terpane; 2- $\mathrm{C}_{22} \mathrm{H}_{40}$ tricyclic terpane; 3- $\mathrm{C}_{23} \mathrm{H}_{42}$ tricyclic terpane; 4- $\mathrm{C}_{24} \mathrm{H}_{42}$ tetracyclic terpane; 5- $\mathrm{C}_{25} \mathrm{H}_{44}$ secohopane; 6- $\mathrm{C}_{26} \mathrm{H}_{48}$ tricyclic terpane; 7- 17 $(\mathrm{H}), 21 \beta(\mathrm{H})$-trisnorhopane; 8- 18 $\alpha(\mathrm{H})-22,29,30$ trisnorhopane (Ts); 9- 17 $\alpha(\mathrm{H})$-22,29,30-trisnorhopane (Tm); 10- 17 $\alpha(\mathrm{H}), 21 \beta(\mathrm{H})$-29-norhopane; 11- 17 $\alpha(\mathrm{H}), 21 \beta(\mathrm{H})$-hopane; $12-17 \alpha(\mathrm{H}), 21 \beta(\mathrm{H})$-homohopano $(22 \mathrm{~S}+22 \mathrm{R}) ; 13-17 \alpha(\mathrm{H}), 21 \beta(\mathrm{H})$-bishomohopane $(22 \mathrm{~S}+22 \mathrm{R}) ; 14-17 \alpha(\mathrm{H}), 21 \beta(\mathrm{H})$-trishomohopane $(22 \mathrm{~S}+22 \mathrm{R}) ; 15-17 \alpha(\mathrm{H}), 21 \beta(\mathrm{H})$-tetrakishomohopane $(22 \mathrm{~S}+22 \mathrm{R}) ; 16-17 \alpha(\mathrm{H}), 21 \beta(\mathrm{H})$-pentakishomohopane (22S+22R).

Bays located in the southern edge of the State of Rio de Janeiro evidenced various areas. These areas were determined using PCA analysis as a function of both natural and anthropic hydrocarbon inputs.

Some stations located in Sepetiba Bay show a clear predominance of anthropogenic pressure such as at station 14 under the influence of Guandu River and São Francisco Channel. High concentrations of NAH, UCM and n-alkanes: 193.8, 179.7 and $8.6 \mu \mathrm{g} \mathrm{g}^{-1}$ dry sediment, respectively, a hopanoid series extending to $\mathrm{C}_{35}$ characterized by epimerization in $\mathrm{C}_{22}(\mathrm{R}+\mathrm{S})$.

At the coastal station 13 close to station 14 , the anthropogenic influence clearly present is dominated by high concentrations of high molecular weight with odd carbon number natural terrestrial $n$-alkanes. Other stations from Sepetiba Bay, far from urbanized and industrialized coasts $(12,15,16)$ appear equally influenced by marine, terrestrial and anthropogenic hydrocarbons with NAH, UCM and $n$-alkane concentrations in the range: 12.0 - 35.7, $8.4-31.3$ and $1.6-2.3$, respectively.

The area centred around the city of Angra dos Reis, which is highly industrialized, with a petroleum terminal and a harbour (stations 4, 5, 6, 8, 9 and 10) show hydrocarbons derived from marine and anthropogenic sources (as suggested by OEPI indices, values of the
$n-\mathrm{C}_{17} / n-\mathrm{C}_{29}$ ratio and presence of highly branched isoprenoids $\mathrm{C}_{20: 1}, \mathrm{C}_{20: 2}, \mathrm{C}_{25: 2}, \mathrm{C}_{25: 3}, \mathrm{C}_{25: 4}, \mathrm{C}_{30: 5}$ and $\mathrm{C}_{30: 6}$ ). While station 9 located close to the petroleum terminal shows indications of petroleum contamination.

The Ilha Grande Bay may be still considered rather pristine in terms of petroleum contamination (stations 1 , 2 and to a lesser extent station 3) with low NAH, UCM and $n$-alkane concentrations: $16.9,19.6,2.5 \mu \mathrm{g} \mathrm{g}^{-1} ; 10.8$, 10.4, $2.0 \mu \mathrm{g} \mathrm{g}^{-1}$ and 3.6, 6.1 and $0.2 \mu \mathrm{g} \mathrm{g}^{-1}$ dry sediment, respectively, $\mathrm{Pr} / \mathrm{Ph}$ ratio values higher than $1, n-\mathrm{C}_{17} / \mathrm{Pr}$, $n-\mathrm{C}_{18} / \mathrm{Ph}$ ratio values below 2.5 .

It became evident that oil contamination is especially important in Sepetiba Bay with other areas like in the north of Grande Island and the vicinities of Angra dos Reis city showing lesser anthropogenic alterations.

\section{Acknowledgments}

This study was funded by the Brazilian Council for Research and Development (CNPq), the Rio de Janeiro State Foundation for Research Support (FAPERJ), and Centre National pour la Recherche Scientifique of France (CNRS). The authors express their gratitude to Dr. Gilberto Dias and Dr. Helio Villena for the assistance in the field work and Miss Anne Lore for the collaboration in the laboratory work. 


\section{References}

1. Summons, R.E. In Organic Geochemistry - Principles and Application; Engel M.H.; Macko S.A., eds; Plenum Press:New York, 1993.

2. UNEP/IOC/IAEA; Reference Methods for Marine Pollution Studies, 20. United Nations Environmental Programme, Intergovernmental Oceanographic Commission and International Atomic Energy Agency, 1992.

3. NRC; Oil in the Sea III: Inputs, Fate, and Effects; The National Academic Press: Washington, D.C, 2003.

4. Blumer, M.; Guillard, R.R.L.; Chase, T.; Mar. Biol. 1971, 8, 183.

5. Youngblood, W.W.; Blumer, M.; Mar. Biol. 1973, 21, 163.

6. Volkman, J.K.; Johns, R.B.; Gillan, F.T.; Perry, G.J.; Geochim. Cosmochim. Acta 1980, 4, 1133.

7. Saliot, A. In Marine Organic Chemistry; Duursma E.; Dawson, R., eds.; Elsevier:Amsterdam, 1981.

8. Bouloubassi, I.; PhD Thesis, Université Paris 6, France, 1990.

9. Summons, R.E.; Barrow, R.; Capon, R.; Hope, J.; Stranger, C; Aust. J. Chem. 1993, 46, 907.

10. Volkman, J.K.; Barret, S.M.; Dunstan, G.A; Org. Geochem. 1994, 21, 407-413.

11. Rullkötter, J. In Organic Geochemistry: Principles and Applications; Engels, M.H.; Macko, S.A., eds; Plenum Press:New York, 1993.

12. Neff, J.M.; Polycyclic Aromatic Hydrocarbons in the Aquatic Environment: Sources, Fates and Biological Effects, Applied Science:Essex, 1979.

13. McCave, I.N; Deep-Sea Res. 1975, 22, 491.

14. Harvey, H.R.; Eglinton, G.; O’Hara, S.C.M.; Corner, E.D.S. In Diversity of Environmental Biogeochemistry; Berthelin, J., ed; Elsevier:Amsterdam, 1991.

15. Lipiatou, E.; Tolosa, I.; Simó, R.; Bouloubassi, I.; Dachs, J.; Marti, S.; Sicre, M.A.; Bayona, J.; Grimalt, J.; Saliot, A.; Albaigés, J; Deep-Sea Res. II 1997, 44, 881.

16. Wakeham, S.G.; Mar. Chem. 1996, 53, 187.

17. Eganhouse, R.P.; Kaplan, I.A.; Environ. Sci. Technol 1982, 16, 541.

18. Philp, R.P.; Elsevier Methods in Geochemistry and Geophysics 23. Elsevier: Amsterdam, 1985.

19. Qiu, Y.J.; Saliot, A.; Mar. Environ. Res. 1991, 31, 287.

20. Bouloubassi, I. ; Saliot, A.; Mar. Chem. 1993, 42, 127.

21. Yunker M.B.; Macdonald, R.W.; Veltkamp D.J.; Cretney W.J.; Mar. Chem. 1995, 49, 1.

22. Weber, R.R.; PhD Thesis, Universidade de São Paulo, Brazil, 1981.

23. Weber, R.R.; Bícego, M.C. In Simpósio sobre Ecossistemas da Costa Sul e Sudeste Brasileira: síntese dos conhecimentos, Cananéia; Academia de Ciências do Estado de São Paulo: São Paulo, 1987.
24. Hamacher, C.; MSc Dissertation, Pontifícia Universidade Católica do Rio de Janeiro, Brazil, 1996.

25. Lima, A.L.C.; MSc Dissertation, Pontifícia Universidade Católica do Rio de Janeiro, Brazil, 1996.

26. Fernandes, M.B.; PhD Thesis, Université Paris 6, France, 1996.

27. Gabardo, I.T.; Meniconi, M.F.G.; Falcão, L.V.; Carreira, R.S. In Proceedings of the 2001 Oil Spill Conference, Florida, 2001.

28. Nishigima, F.N.; Weber, R.R.; Bícego, M.C.; Mar. Pollut. Bull. 2001, 42, 1064.

29. Medeiros, P.M.; Bícego, M.C.; Mar. Pollut. Bull. 2004, 49, 761.

30. Medeiros, P.M.; Bícego, M.C.; Mar. Pollut. Bull. 2004, 49, 892.

31. Medeiros, P.M.; Bícego, M.C.; Castelao, R.M.; Del Rosso, C.; Fillman, G.; Zamboni, A.J.; Environ. Int. 2005, 31, 77.

32. PLANAVE. Estudos de Impactos Ambientais do Projeto de Ampliação da Área de Estocagem, Manuseio e Reprocessamento de Minério na Ilha Guaíba; PLANAVE Estudos e Projetos de Engenharia S.A.:Rio de Janeiro, 1992.

33. Adler, R.; Souza, A.B.; Revista FEEMA 1995, 18, 26.

34. TURISRIO; Plano Diretor de Desenvolvimento de Pólos de Turismo Náutico no Estado do Rio de Janeiro, Volume 1: Síntese do Diagnóstico Básico; Companhia de Turismo do Estado do Rio de Janeiro:Rio de Janeiro, 1990.

35. FEEMA; Rio Guandu: qualidade de água da bacia hidrográfica e estação de tratamento. Fundação Estadual de Engenharia e Meio Ambiente do Rio de Janeiro: Rio de Janeiro, 1989.

36. Guimarães, J.R.D.; Lacerda, L.D.; Teixeira, V.L.; Rev. Bras. Biol. 1982, 42, 553.

37. Lacerda, L.D.; Pfeiffer, W.C.; Fiszman, M.; Cienc Cult. 1982, 34, 921 .

38. Lacerda, L.D.; Martinelli, L.A.; Rezende, C.E.; Mozeto, A.A.; Ovalle, A.R.C.; Victoria, R.L.; Silva, C.A.R.; Nogueira, F.B.; Sci. Total Environ. 1988, 75, 169.

39. Peltzer, E.T.; Alford, J.B.; Gagosian, R.B. In Technical Reports 84-9, Woods Hole Oceanographic Institution: Massachusetts, 1984.

40. Folk, R. ; Ward, W.; J. Sed. Petrol. 1957, 27, 3.

41. Bouloubassi, I.; Saliot, A.; Oceanol. Acta 1993, 16, 145.

42. Bícego, M.C.; Contribuição ao Estudo de Hidrocarbonetos Biogênicos e do Petróleo no Ambiente Marinho; Editora Resenha Tributária: São Paulo, 1988

43. Eglinton, G.; Hamilton, R.J.; Science 1967, 156, 1322.

44. Prahl, F.G.; Carpenter, R.; Geochim. Cosmochim. Acta 1979, 43, 1959.

45. Meyers, P.A.; Ishiwatari, R.; In Organic Geochemistry: Principles and Applications; Engels, M.H.; Macko, S.A., eds; Plenum Press: New York, 1993

46. Clark Jr., R.C.; Blumer, M.; Liminol. Ocenaogr. 1967, 12, 79. 
47. Scalan, R.S.; Smith, J.E.; Geochim. Cosmochim. Acta 1970, 34, 611.

48. Steinhauer, M.S.; Boehm, P.D.; Mar. Environ. Res. 1992, 33, 223.

49. Colombo, J.C.; Pelletier, E.; Brochu, C.; Khalil.; M.; Catoggio, J.A.; Environ. Sci. Technol. 1989, 23, 888.

50. Venkatesan, M.I.; Kaplan, I.R.; Geochim. Cosmochim. Acta 1982, 46, 2135.
51. Grimalt, J.O.; Torras, E.; Albaiges, J.; Org. Geochem. 1988, 13, 741.

52. Volkman, J.K.; Barret, S.M.; Blackturn, S.I.; Mansour, M.P.; Sikes, W.L.; Gelin, F.; Org. Geochem. 1998, 29, 1163.

53. Hirb, S.J.; Rowland, S.J.; Mar. Environ. Res. 1995, 40, 423.

Received: April 4, 2007 Web Release Date: March 7, 2008 